PF 2019 (LXXIV): 315-328

\title{
MOTOKI NOMACHI
}

Slavic-Eurasian Research Center

Hokkaido University

Kita 9 Nishi 7 Kita-ku Sapporo

tel. +819039620839

e-mail: mnomachi@slav.hokudai.ac.jp

\section{PLACING KASHUBIAN \\ IN THE CIRCUM-BALTIC (CB) AREA}

SŁOWA KLUCZOWE: Bałtycka liga językowa, kaszubszczyzna, języki bałtyckie, języki słowiańskie, języki fińskie.

KEYWORDS: Circum-Baltic area, Kashubian, Baltic languages, Slavic languages, Finnic languages.

\section{MIEJSCE KASZUBSZCZYZNY W BAŁTYCKIEJ LIDZE JĘZYKOWEJ}

\begin{abstract}
W niniejszym artykule analizie poddana jest kaszubszczyzna z perspektywy kontaktu językowego, zwłaszcza w obrębie tzw. bałtyckiej ligi językowej (CircumBaltic area). W pierwszej części podjęto dyskusję o miejscu kaszubszczyzny na mapie językowej, wraz z jej badaczami, wymieniającymi ten język w pracach poświęconych badaniu ligi językowej. Ukazano także, że żadna $\mathrm{z}$ tych prac nie jest poprawna nie tylko w warstwie teoretycznej, lecz również w przytoczonych przykładach i ich interpretacji. Druga część poświęcono krytycznej analizie szeregu prac Koptjewskiej-Tamm, Östena Dahla i Bernharda Wälchliego. Część trzecia pokazuje, że język kaszubski nie należy do ligi językowej obszaru Morza Bałtyckiego, mimo że geograficznie umiejscowiony jest w tej zachodniej strefie. Rozpatrywane są również możliwe kontakty językowe między kaszubskim a innymi językami w obrębie tej strefy.
\end{abstract}

\section{Introduction}

Prof. Dr. hab Janusz Siatkowski, one of the most eminent specialists in Slavic dialectology in the 20th and 21st centuries, is known as a specialist in Kashubian 
as well. When I was a lecturer at the University of Warsaw in 2003-2005, I was fortunate enough to take Prof. Siatkowski's Slavic dialectology course, in which I read Kashubian dialect texts for the first time as a course assignment. Ultimately, that experience led me to Kashubian studies. In a private conversation in Kamakura, an old capital of Japan near Tokyo, in February 2017, Prof. Siatkowski and I were talking about the future aims of Kashubian studies. Prof. Siatkowski told me that the contact phenomena should be studied thoroughly from various perspectives, with particular attention to syntactic phenomena, which are missing even in the Atlas of Kashubian and Neighboring Dialects (1964-1978), for which Prof. Siatkowski has worked. The following text is an overview of ideas inspired by the conversation with Prof. Siatkowski.

Kashubian is a so-called "high-contact” language (Nomachi, Heine 2011). This language has been under the influence of various local languages and politically dominant languages spoken or used in the Pomerania region (Lorentz et al. 1935: 5-9, Knoll 2012: 11-13). However, Kashubian has not been mentioned in the context of areal typology, at least not frequently. There seem to be two main reasons for this. First, particularly in the earliest stage of profiling a given linguistic area from a macro perspective, the standard variety of languages in the area is the target of analysis. Kashubian, which does not have an established standard variety and was regarded until recently as a dialect of Polish, naturally did not attract much attention (Haspelmath 2001 and many others for Standard Average European, henceforth SAE), Newerkla 2007, Bláha 2016 for various Central European areas). Second, although Kashubian has attracted attention in the context of language contact, for instance (as one can see in the numerous works by Hanna Popowska-Taborska, Friedhelm Hinze, and others), the focus was rather limited, above all, on the level of the lexicon in the two languages that were in contact.

Thus, in this article, I will try to characterize Kashubian from an areal-typological perspective, with particular attention to the Circum-Baltic (CB) area as the first step.

\section{A few words about previous works on areal linguistics mentioning Kashubian}

Indeed, there are a few exceptions in this respect. For instance, in the frame of his phonology-based areal analysis, Jakobson treated North Kashubian or Slovincian in the context of his Eurasian Linguistic Area, in which it joins the linguistic area in question as a language characterized by polytonicity (Jakobson 
1931 [1962], 157). However, as it has been pointed out by Lehiste (1988), Jakobson relied on Lorentz's misguided interpretation of the accentual system in Slovincian (cf. Lorentz 1903), which has been discussed by Stokhof (1973: 133) and Stankiewicz (1993: 292).

Another example is the so-called „Rokytno-Bund” suggested by Décsy (2000: 130). According to this scholar, this is one of the linguistic zones in Europe, and it includes Lithuanian, Belarusian, Ukrainian, Kashubian, and Polish that was the dominant language. The common linguistic features are as follows (Décsy 2000: 132):

1. no quantity correlation (no distinctions in length; Lithuanian and Kashubian are exceptions);

2. mobile word accent (Polish as well as the eastern Kashubian dialects are an exception);

3. no reduced vowels in unstressed syllables (they are fully sounded; Belarusian is an exception);

4. no diphthongs (Lithuanian, which has ie as well as $u o$, is an exception);

5. existence of the consonant $h$;

6. fricatives play a considerable role in the consonantism;

7. open $e(\ddot{a})$ is not spread (except for Lithuanian);

8. correlation of palatals is greatly expanded, but not as thoroughly as in Russian;

9. multiple noun classes („declension types”), in part based on gender;

10. the case structure has preserved archaic features (the genitive in $-u$; the change of $k, g$, ch before old $\check{e}$ and $i$ );

11. there is a lively structure of aspect;

12. verbal prefixes (non-separable);

13. impersonal participle constructions (Ukrainian dveri idecineno 'the door is open' $[$ sic! $])^{1}$;

14. presence of the verb 'to have' rooted in popular speech;

15. a vast number of common coinages in the vocabulary (lexical Rokytnism, generally of Polish origin)

With regard to Kashubian, the features 1, 2, 4, 5, and 13 are not relevant ${ }^{2}$, while other features do not always seem to be areal features per se. In addition,

1 The correct Ukrainian sentence is dveri vidčyneno.

2 For feature 1, Kashubian does not have a correlation of the vowel length; feature 2 is wrong because fully mobile accent can be found in Northern dialects, while Central dialects have a column type of accentuation; for feature 4, Kashubian does have diphthongs such as $\grave{u}, \dot{o}$ [we, wu]; Unlike in the generalization for feature 5, Kashubian does not have the phoneme $h$; feature 13 is wrong because Kashubian does not have the impersonal construction found in Ukrainian and Polish. 
he gave a brief characteristic of Kashubian (Décsy 2000: 149-150). Most interpretations and even reported facts are basically wrong ${ }^{3}$.

In search of Standard Average European (Europe as a linguistic area), it probably was Heine and Kuteva (2006) who mentioned Kashubian with Slovincian for the first time as SAE's peripheral member because of its contact with German. However, these scholars analyzed only the possessive perfect and a passive construction ${ }^{4}$. Besides, in the EUROTYP project, Tommola (2000) characterizes the perfect in Northern Slavic, including Kashubian. However, he simply repeated what was already known and there is no analysis of this language either.

Dahl and Koptjevskaja-Tamm (2001: XIX), who wrote one of the standard works on the areal-typology of the Circum-Baltic area, include Kashubian in the list of Western Slavic languages that constitute this linguistic landscape. However, it is unclear if Kashubian can be regarded as a member of this contact zone, or it is only geographically involved in the linguistic zone. In addition, there is not a single example analyzed in the entire volume. In a later work by Koptjevskaja-Tamm (2006: 199), the disputed Kashubian polytonicity was the only example mentioned. Another CB scholar, Wälchli (2011: 331), provided an example of Kashubian for illustrating the non-pro-drop tendency in this language.

Thus, even though there were various works mentioning Kashubian as a member of a given linguistic area, not a single proper areal profiling of Kashubian has been done yet. In addition, all these works are problematic because they did not consider enough the diachronic and sociolinguistic changes in the area, including contact situations that have surrounded Kashubian. Indeed, such changes clearly have affected the linguistic structure of Kashubian. Thus, one cannot extract an example from the material recorded in the 19th century and compare it with examples from other languages taken in the 21 st century ${ }^{5}$.

3 In this paper I cannot get into details, but it would be enough to provide just one crucial example to show how the treatment of Kashubian by this scholar is catastrophic. According to Décsy, ,the compound preterite (past tense) is not formed with a verb of being (as in the other Slavic languages) but with the verb of "having" (as in English and German) ja mom widzet 'I have seen', and not ja jem widzel." Needless to say, such a form as ja mom widzet does not exist in Kashubian, while the latter, though the author denies its existence, is correct (to be more precise, it should be jô jem widzôt).

4 Heine and Kuteva (2006) did mention Kashubian in their book, in two chapters that deal with definite and indefinite articles, but without any concrete examples.

5 I would like to express my sincere gratitude to Mr. Artur Jabłoński and Mr. Grzegorz Schramke who have provided me with the material of the Kashubian language. 


\section{The CB area: its members, nature, and areal features}

Language membership. Dahl and Koptjevskaja-Tamm (2001: XVII) point out difficulties in defining the set of members, because, first, it is not always clear how far from the Baltic coast a language can be and still be treated as a member; second, there are contact languages such as Latin and French, that can be important in the case of the $\mathrm{CB}$ area; third, the distinction between a language and a dialect is not always sharply-defined. Thus, with some simplifications, Dahl and Koptjevskaja-Tamm (2001: XVIII-XIX) include the following languages as Circum-Baltic languages ${ }^{6}$ :

Germanic:

West: High German, Low German, Yiddish;

North: Danish, Swedish, Dalecarlian, Norwegian;

Baltic:

West: †Old Prussian, ††Curonian, †Jatvingian ${ }^{7}$;

Central: Lithuanian, Latvian;

East: $\dagger \dagger$ Galindian ${ }^{8}$;

Slavic:

West: Polish, Kashubian, †Polabian;

East: Belarusian, Russian, Ukrainian;

Indo-Aryan:

Romani with varieties/sub-languages: Kalderash, Lovari, Kalo, Baltic, North Russian;

$6 \dagger$ means „extinct” and $\dagger \dagger$ means only onomastic sources and substratum are available.

7 Galindian was in all likelihood a West Baltic language. One wonders whether Dahl and Koptjevskaja-Tamm (2001) had in mind the language of the Goljad' ( ${ }^{*}$ Galindi-) of the Old Russian chronicles, which was spoken until the 12th c. in the Porotva (Protva) river valley west of Moscow. However, the affiliation of that "other Galindian language” with East Baltic is not an established fact (Yaroslav Gorbachov, in personal commmunication).

8 Jatvingian is only known from toponomastic and anthroponomastic data, therefore it should have two „daggers” like Curonian and Galindian, instead of one. Dahl and Koptjevskaja-Tamm 2001 seem to take Zinov's Jatvingian-Polish glossary (Gwary pogańskie $z$ Narewu) for an authentic document. However, its authenticity is far from demonstrated. „In the recently „found” PolishJotvingian glossary (cf. Zinkevičius 1984) some of the words... reflect the „Lithuanian treatment” of the postalveolar sibilants, cf. sziasz 'six' (Lith. šeši), miszta 'forest' (Lith. miškas), żuwo 'fish (pl.)' (Lith. žuvis), etc. Yet multiple other words show the expected West Baltic reflexes, e. g., puse 'pine tree' (Lith. pušis), birs 'birch' (Lith. béržas), maz 'small' (Lith. mãžas), etc. There are other phonological and morphological incongruities in this document, which has every appearance of a forgery. It exists only in a hand-made copy from the 1970s. The original that nobody, apart from the copier, saw, „has not survived” (Gorbachov 2014: 38, fn. 39). 
Finno-Ugrian:

Finnic: Veps, Karelian, Olonetsian, Ludian, Finnish, Ingrian, Votian, Estonian with varieties/sub-languages: South Estonian, Northern Estonian,

Saami with varieties/sub-languages: Southern Saami, Ume, Saami, Pite Saami, Lule Saami, Northern Saami, Inari Saami, Skolt Saami;

Turkic:

Karaim, Tatar.

In contrast, Wälchli (2011: 325-327) does not include Ukrainian and extinct Polabian, while he counts Old Prussian as a CB language. Needless to say, in the case of Ukrainian and Polabian, the distinction between a language and a dialect does not matter too much, thus it is not a question of the way they are counted. The question, of course, is: what are the reasons to include/exclude these languages? The representative scholars in this field do not seem to have given a proper answer in this respect.

\section{The nature of the $\mathrm{CB}$ area}

The view on the CB area as a linguistic one is not uniform. Thomason (2001: 99) defines a linguistic area as follows:

a linguistic area is a geographical region containing a group of three or more languages that share some structural features as a result of contact rather than as a result of accident or inheritance from a common ancestor.

Further, Thomason (2001: 110) opines as follows:

Probably the best-established linguistic area of Europe after the Balkans is in northeastern Europe in the region around the Baltic Sea, where several languages belonging to two, or possibly three, different families form a Sprachbund.

Almost the same statement can be found in Campbell (2004: 337). However, considering areal features provided by Koptjevskaja-Tamm and Wälchli (2001: 728), which are mentioned in the next section, one can notice that there is not a single areal feature that is shared by all the languages in the CB area. Indeed, Wälchli (2011: 325) is of a different opinion from Thomason:

The motivation to treat CB languages together stems from the many typological parallels between not genealogically definable subsets of languages and dialects testifying to the turbulent history of the area. The $\mathrm{CB}$ area is a contact superposition zone rather than a Sprachbund and is part of a „buffer zone” between SAE and Central Eurasia.

In addition, according to Koptjevskaja-Tamm (2006: 187), the most striking cross-linguistic isoglosses in the $\mathrm{CB}$ area are mainly found in its eastern part. 
This has been confirmed by Timberlake (2017: 336-341), who has analyzed three different layers of Eastern Baltic Region as a linguistic contact zone. Then, one may wonder if there is any reason to treat all languages as belonging to one area, particularly in the western part of the CB area. Indeed, Koptjevskaja-Tamm (2006: 205) raised a question: if there are two semicircles (eastern and western) or one circle in the CB area. To this question Koptjevskaja-Tamm answers that it would be two semicircles in the CB area, based on the polytonicity only.

\section{The CB areal features}

According to Campbell (2004: 331), there are two sorts of studies of linguistic areas:

the more common approach, called circumstantialist, mostly just lists of similarities found in the languages of a geographical area, allowing the list of shared traits to suggest diffusion....The other approach, called historicist, attempts to find concrete evidence showing that the shared traits are diffused.

As Campbell himself confirmed, the latter approach is preferable because the former „does not eliminate chance, universals, and possibly undetected genetic relationships as alternative possible explanations for shared traits". Although the latter is not always possible, in the studies of the $\mathrm{CB}$ area, the historicist approach has not always been undertaken, particularly in the case of Slavic languages that Koptjevskaja-Tamm and Wälchli include/exclude as members of this specific linguistic zone.

According to Koptjevskaja-Tamm (2006: 193), there are three properties that are „most promising cases for being Circum-Balticisms, though none will stand the proof of coming the full circle of around the Baltic Sea" (see the features listed below under A.) In addition to these features, she suggests six areal phenomena in grammar (Koptjevskaja-Tamm 2006: 186):

A. Most promising features in the $\mathrm{CB}$ area

1. Polytonicity

2. Initial stress

3. Rigid GenN word order combined with the flexible SVO basic order

B. Main isoglosses in the $\mathrm{CB}$ area

4. Case alternation for marking total versus partial objects/subjects

5. Nominative object in various constructions

6. Case alternation in predicate adjectives and nominals

7. Alternation between case-government and agreement within numeral construction 
8. Evidential mood

9. Reflexive postfixes as markers of valence recession

There may be other features to be found and discussed to profile languages in this area, but this set of features is enough to let us discuss the possible placement of Kashubian in the CB area.

\section{Profiling Kashubian in light of the CB areal features}

Table 1 below is a summary of the results of applying the above-mentioned nine $\mathrm{CB}$ areal features for Kashubian:

Table 1. CB areal features applied for Kashubian

\begin{tabular}{|c|c|c|c|}
\hline Feature & $\begin{array}{l}\text { Presence/Absence } \\
\text { of Feature }\end{array}$ & Example & Judgement \\
\hline 1 & No & & \\
\hline 2 & (Yes) & Only in the southern dialect & Internal evolution \\
\hline 3 & (Yes) & $\begin{array}{l}\text { na Geratowëch } \\
\text { 'ons.adj. } \\
\text { 'on Gerat's parents' } \\
\text { To je tegò króla } \\
\text { gen zómk. 'This } \\
\text { is the castle of the king.' } \\
\text { But the following constructions } \\
\text { are also possible: } \\
\text { na starszich Gerata } \\
\text { To je zómk tegó króla } \\
\text { gen }\end{array}$ & Genetic feature \\
\hline 4 & Yes & $\begin{array}{l}\text { Kònie żarłë sana gen } \\
\text { 'Horses ate some hay.' }\end{array}$ & $\begin{array}{l}\text { Genetic feature/ } \\
\text { (very old) areal } \\
\text { feature? }\end{array}$ \\
\hline 5 & No & & \\
\hline 6 & (Yes) & $\begin{array}{l}\text { Chto }{ }_{\text {nom }} \text { të jes? } \\
\text { 'Who are you?' } \\
\text { Kim }_{\text {ins }} \text { më jesmë? } \\
\text { 'Who are we?' }\end{array}$ & $\begin{array}{l}\text { Genetic/areal } \\
\text { feature? }\end{array}$ \\
\hline 7 & No & $\begin{array}{l}\text { Jô dôł na talerz piã } c_{\text {nom/acc }} \\
\text { złotëch } \\
\text { 'I gave five zloty on the plate.' }\end{array}$ & Internal evolution \\
\hline
\end{tabular}




\begin{tabular}{|c|l|l|l|}
\hline & & $\begin{array}{l}\text { Òn przed piãc } c_{\text {nom.acc }} \text { latama }_{\text {ins.pl }} \\
\text { ògłosył swiatu, że... } \\
\text { 'Five years ago, he informed the } \\
\text { world that... }\end{array}$ & \\
\hline 8 & No & & \\
\hline 9 & No & & \\
\hline
\end{tabular}

A few comments to on the "positively identified" features in Table 1.

Feature 2. The southern dialect is characterized by the presence of the initial stress. This feature does not require an explanation based on contact-induced change. (cf. Topolińska 1961: 107)

Feature 3. Unlike standard Polish or Russian, Kashubian has the possessive adjective as a productive category and this language prefers it to the post-posed genitive case wherever semantically and syntactically possible. The preference of the pre-posed possessive adjective for meaning an animate possessor is a genetic feature inherited from Proto-Slavic. Moreover, the pre-posed genitive case is possible, and, at a first glance, this situation may seem to coincide with that of dialects of Polish or Russian in the CB area, but in the case of Kashubian, it is not a particularly preferred word order and post-posed genitive case is also found without a stylistic difference.

Feature 4. This feature is a common development in Slavic languages (Vaillant 1977: 76) and the same or similar use of the genitive case was widespread in other Indo-European languages (cf. Krasuxin 2005: 54-56). Meillet (1934: 464465) regards the partitive genitive case is of a common Indo-European origin. According to Pirnat (2015: 25), Finnish partitive is a Balto-Finnic innovation. Proto-Balto-Slavic partitive construction is most likely an older phenomenon. However, it is not clear if this feature serves as a convincing one today, because this feature is a pan-Slavic feature, and as such, predates the break-up of Common Slavic.

Thus, in spite of the presence of this feature in Kashubian, it may be difficult to regard this feature areally motivated one and shared with other CB language in mutual language contact.

Feature 6. In the contemporary Kashubian language this alternation seems to appear more often than before in predicative nominals (cf. Wosiak-Śliwa 1996). A fine-grained quantitative research should be done, before the evolution of this use of the case form is completed.

According to Lorentz (1919: 60) and Stone (2002: 783), following Lorentz, the nominative case is used for indicating a permanent characteristic. However, this semantic distinction does not seem to work, as can be seen in the title 


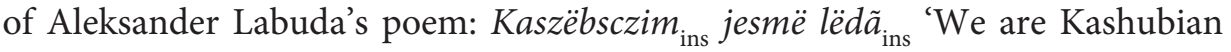
people.'

With regard to adjectives in this respect, the nominative-instrumental case alternation is rather restricted. Usually, the nominative case is used when the adjective appears alone with a copular bëc 'to be': Trojanowskô bëła nadzwëc$z a j n \hat{o}_{\text {nom }}$ 'Trojanowska was extraordinary,' while the case alternation appears in favor of the instrumental case, when an infinitive form of the copular is collocated: chce bëc samòstójnëma $a_{\text {ins }}$ ('They) want to be independent.' Considering the fact that this feature is a later development in the Slavic languages, among which it is almost missing in the Slavic South, as has been pointed out by Bernštejn (1958: 22), this could be an areal feature in the CB area. On the other hand, one could not absolutely exclude a possibility that this feature is a genetic feature within West Slavic (cf. Stanislav 1973 for Slovak, Gebauer 1929 for Czech). In any case, the feature did not come from the Eastern Baltic zone.

Feature 7. The feature does not exist in Kashubian, as it is somewhat simplified if compared to Polish, e.g., in Kashubian, the numerals higher than 'five' do not change their forms, and the nouns are directly governed by the prepositions.

To conclude, from the circumstantialist perspective, Kashubian might share four suggested areal features, but, in reality or historically speaking, those features have presumably nothing to do with the concept of the CB area as a certain convergence area, except for Feature 4 or Feature 6 that could be related to contact with Polish. Thus, even though Kashubian is situated in this area, it is rather doubtful whether this language could be treated as a member per se.

\section{Kashubian in contact with the CB languages}

The previous paragraph might have raised the question whether there have been any contact situations with the CB languages, particularly the western ones. Disappointingly, although historically there might have been such contacts, there does not seem to be a clear answer in terms of linguistic material. Even though there might have been a direct contact with those languages, the materials that could be found in Kashubian seem to be rather scanty.

\section{Baltic-Kashubian contact}

Of particular interest in this respect has been Old Prussian (Lorentz 1962: 42, Milewski 1939-1947). However, according to Popowska-Taborska (1992), 
there does not seem to be direct contact between Kashubian and Old Prussian, as the latter's settlements never went deeply into the Pomeranian region. Thus, all seemingly Old Prussian words in Kashubian might have been borrowed in a much older period in the early Baltic-Old Polish contact or via German.

On the other hand, Old Prussian and Kashubian spoken before World War II may share various features. Though not fully grammaticalized, in both languages one can find constructions like: a demonstrative pronoun as a definite article, a numeral 'one' as an indefinite article (cf. Knoll 2012, Mathiassen 2010: 36), merger of the instrumental and comitative cases (cf. Nomachi and Heine 2011, Mathiassen 2010: 69), the verb 'give' as an auxiliary for the permissive and causative constructions (cf. Pakerys 2017). The penultimate feature is shared with Polabian and the last feature with some Baltic and Finnic languages. Is this enough for one to begin to entertain the idea of a linguistic zone? Probably not, because the features do not require any areal account and it might have been just a one-sided German influence that happened in a different space and time, which could have happened in various areas where German occupied a dominant position.

\section{Scandinavian-Kashubian contact}

There has been no substantial research in this area. Whatever modest attempts did take place, have yielded more than modest results. According to Lorentz (1962: 42), the Kashubian name Swian can be explained as a borrowing from Scandinavian Svenn. In addition, there seem to be a few toponyms of Scandinavian origin. To the best of my knowledge, there are no historically motivated relevant areal features.

\section{Finno-Ugric-Kashubian contact}

To the best of my knowledge, so far, nobody has been able to demonstrate definitively any substantial Finno-Ugric influence on Kashubian. Until such a demonstration has been accomplished, one should assume no prehistoric contact with Uralic. 


\section{Instead of a conclusion}

What I have presented is a brief overview of both theoretical and empirical aspects of the $\mathrm{CB}$ area vis-à-vis Kashubian. Brief as it may be, what emerges quite clearly is that Kashubian should not be placed in the CB area as a constituting member of this zone. It shares almost nothing with other CB languages, when one approaches the matter within the historicist framework, even though geographically it is indeed situated within the CB area. There do not seem to exist small linguistic areas that could include Kashubian in this context. Seemingly shared traits can also be explained as resulting from internal evolution, or by contact either with Polish or German, which does not require an explanation from a linguistic area viewpoint.

Wälchli's „buffer zone between SAE and Central Eurasia” (2011) may be theoretically correct, but it may not help much in accounting for Kashubian's position in the CB area. Some non-SAE features shared with Polish, a CB language according to $\mathrm{CB}$ scholars, do not seem to have any relation with the $\mathrm{CB}$ area. On the other hand, by the end of World War II Kashubian had incorporated various German grammatical features (for instance, indefinite and definite articles, non-prodrop-feature, the 'have'-perfect, merger of the instrumental and comitative cases) shared with SAE languages. Thus, it can be said that the nonSlavic features established by contact-induced linguistic change in Kashubian are mostly to be regarded as various processes of the secondary Europeanization and should be discussed in this context, not in the context of the CB area.

\section{References:}

Bernštejn Samuil (red.), 1958, Tvoritel’nyj padež v slavjanskix jazykax, Moscow. Bláha Ondřej 2015, Jazyky střední Evropy, Olomouc.

Campbell Lyle, 2004, Historical Linguistics: An Introduction, Cambridge, Massachusetts. Dahl Östen, Maria Koptjevskaja-Tamm (eds.), 2001, Circum-Baltic languages. Volume

1: Past and present, Amsterdam-Philadelphia.

Dahl Östen, Maria Koptjevskaja-Tamm (eds.), 2001, Circum-Baltic languages. Volume 2: Grammar and typology, Amsterdam-Philadelphia.

Décsy Gyula, 2000, The Linguistic Identity of Europe. Part 1: The 62 Languages of Europe Classified in Functional Zones, Bloomington, Indiana.

Gebauer Jan, 1929, Historická mluvnice jazyka českého. Díl IV. Skladba, Praha.

Gorbachov Yaroslav, 2014, The Origin of the Baltic Inchoative in -sta-. An Overlooked Proto-Baltic Sound Law, „Indogermanische Forschungen”, No. 119, Berlin.

Haspelmath Martin, 2001. The European Linguistic Area: Standard Average European, [in:] Language Typology and Language Universals, eds. Martin Haspelmath, Ekkehard König, Wolfgang Oesterreicher and Wolfgang Raible, Berlin-New York. 
Heine Bernd, Kuteva Tania, 2006, The Changing Language of Europe, New York. Jakobson Roman, 1931 (1962), K xarakteristike evrazijskogo jazykovogo sojuza, [in:] Selected Writings I, The Hague.

Knoll Vladislav, 2012, Kašubština v jazykovém kontaktu, Praha.

Koptjevskaja-Tamm Maria, 2006, The Circle That Won't Come Full: Two Potential Isoglosses in the Circum-Baltic Area, [in:] Linguistic Areas: Convergence in Historical and Typological Perspective, eds. Yaron Matras, April McMahon, Nigel Vincent, Basingstoke-New York.

Krasuxin Konstantin, 2005, Očerki po rekonstrukcii indoevropejskogo sintaksisa, Moscow.

Lehiste Ilse, 1988, Lectures on Language Contact, London-Cambridge.

Lorentz Friedrich, 1903, Slovinzische Grammatik, Sankt-Petersburg.

Lorentz Friedrich, 1919, Kaschubische Grammatik, Danzig.

Lorentz Friedrich, Fischer Adam, Lehr-Spławiński Tadeusz, 1935, The Cassubian Civilization, London.

Lorentz Fryderyk, 1962, Gramatyka pomorska I, Wrocław.

Mathiassen Terje, 2010, Old Prussian, Oslo.

Meillet Antoine, 1934, Le Slave Commun, Paris.

Milewski Tadeusz, 1939-47, Stosunki językowe polsko-pruskie, „Slavia Occidentalis”, t. XVIII, Poznań.

Newerkla Stefan, 2007, Areály jazykového kontaktu ve stř̌ední Evropě a německo-český mikroareál ve východním Rakousku, „Slovo a slovesnost”, r. 68, Praha.

Nomachi Motoki, Bernd Heine, 2011, On Predicting Contact-induced Grammatical Change: Evidence from Slavic Languages, „Journal of Historical Linguistics”, No. 1, Berlin.

Pakerys Jurgis, 2017, Old Prussian dāt 'give' in Causative and Hortative Constructions, „Baltic Linguistics”, Vol. 8, Vilnius.

Pirnat Žiga, 2015, Genesis of the Genitive of Negation in Balto-Slavic and Its Evidence in Contemporary Slovenian, „Slovene Linguistic Studies”, Vol. 10, Laurence.

Popowska-Taborska Hanna, 1992, O pewnych wyrazach kaszubskich uchodzących za bałtyzmy, [w:] Polono-Slavica Varsoviensia. Słowiańsko-niesłowiańskie kontakty językowe, red. Janusz Siatkowski, Ignacy Doliński, Warszawa.

Stanislav Jan, 1973, Dejiny slovenského jazyka. Syntax 1, Bratislava.

Stankiewicz Edward, 1993, The Accentual Patterns of the Slavic Language, Standford, California.

Stokhof Willem, 1973, The Extinct East-Slovincian Kluki-Dialect, Paris.

Stone Gerald, 2002, Cassubian, [in:] The Slavonic Languages, eds. Bernard Comrie, Greville G. Corbett, London-New York.

Thomason Sarah Grey, 2001, Language Contact: An Introduction, Washington, D. C. Timberlake Alan, 2017, Slavic Languages, [in:] The Cambridge Handbook of Areal Linguistics, ed. Raymond Hickey, Cambridge.

Tommola Hannu, 2000, On the Perfect in North Slavic, [in:] Tense and Aspect in the Languages of Europe, ed. Östen Dahl, Berlin-New York.

Topolińska Zuzanna, 1961, Z historii akcentu polskiego od wieku XVI do dziś, WrocławWarszawa-Kraków. 
Vaillant André, 1977, Grammaire Comparée des Langues Slaves. Tom 5. La Syntaxe, Paris. Wälchli Bernhard, 2011, The Circum-Baltic Languages, [in:] The Languages and Linguistics of Europe: a Comprehensive Guide, eds. Bernd Kortmann, Johan van der Auwera, Berlin.

Wosiak-Śliwa Róża, 1996, Uwagi o składni w utworach północnokaszubskich pisarzy Jana Bilota i Alojzego Budzisza, „Rocznik Gdański”, t. LVI, 1, Gdańsk. Zinkevičius Zigmas, 1984, Lietuvių kalbos istorija, Mokslas.

\section{Streszczenie}

Celem niniejszego artykułu jest umiejscowienie kaszubszczyzny na lingwistycznej mapie tzw. bałtyckiej ligi językowej (Circum-Baltic area). W tekście kaszubszczyzna analizowana jest pod kątem kilku istotniejszych cech dla tej ligi językowej według O. Dahla, M. Koptjevskiej-Tamm, B. Wälchliego i innych. 